\title{
Effect of Wall Materials and Inlet Air Temperatures on Physical Properties of Microencapsulated of Olive Oil Powder
}

\author{
C. Ashokkumar ${ }^{1 *}$, B. Murugan ${ }^{1}$, D. Baskaran ${ }^{2}$, V. Veerapandian ${ }^{3}$ and A. Karthiayani ${ }^{1}$ \\ ${ }^{1}$ College of Food and Dairy Technology-TANUVAS, Chennai-52, India \\ ${ }^{2}$ Faculty of Food Sciences, College of Food and Dairy Technology-TANUVAS, Chennai- 52 \\ ${ }^{3}$ Department of Livestock Products Technology (Dairy Science), \\ MVC-TANUVAS, Chennai-07, India
}

*Corresponding author

\author{
A B S T R A C T
}

\begin{tabular}{|l|}
\hline Ke y w or d s \\
Olive oil, \\
Microcapsules, \\
Spray drying, \\
\hline Article Info \\
\hline $\begin{array}{l}\text { Accepted: } \\
18 \text { April } 2018 \\
\text { Available Online: } \\
10 \text { May } 2018\end{array}$ \\
\hline
\end{tabular}

\section{Introduction}

Microencapsulation is the process of producing tiny particles or droplets which are surrounded by a coating material or embedded in a homogeneous or heterogeneous matrix to form small capsules with core (Calvo et al., 2011). Although many techniques exist to encapsulate food ingredients, spray draying method is the most common technology used in food industry due to low cost and availability of equipment. Compared to freeze drying, the cost of spray drying is 30 to 50 times lower (Desorbry et al., 1997).

Olive oil is a good source of health promoting food product that finds wide application in food industry. The fatty acids content in olive oil is very valuable, because of its high concentration of unsaturated linoleic and oleic acids.

Oxidation of oil in water emulsions has increased (Coupland, 1996; German, 1999; 
$\mathrm{Hu}, 2003)$. One of the main reasons is the production and availability of many emulsiontype food articles.

Olive oil is rich in unsaturated fatty acids and phenolic compounds, which are highly beneficial to consumers in the form of ready to eat foods and healthy food products. Lipid oxidation is a major problem in food industry for processing and storing of foods containing oils in their formulations. Oxidation of oil leads to the formation of toxic products such as peroxides or undesirable off flavor compounds and determines the shelf life of the product (Sun Waterhouse et al., 2011).

The coating material for spray drying should have a bland flavour, high solubility, and possesses the necessary emulsification, film forming and good drying properties (Young et al., 1993). An important step in developing microcapsules is the selection of a wall material that, wall could act as a barrier and it may protect against oxygen, water, light or could avoid contact with other ingredients or control diffusion. Numerous wall materials have been studied and used for their suitability as encapsulating agents in spray drying. Wall materials for microencapsulation of oil by spray drying must have emulsifying properties, high water solubility, low viscosity, and drying properties (Bae and Lee 2008).

Highest encapsulation yields were achieved when gelatin, arabic gum and maltodextrin and sodium caseinate and maltodextrin were used as encapsulation agents and the ratio of wall and oil was 1:4 and 1:2, respectively (Calvo et al., 2010). Therefore, olive oil encapsulation may be useful to retard lipid auto oxidation and increase the range of applications in food industry where otherwise oil could not be used.

\section{Materials and Methods}

\section{Materials}

Olive oil purchased from the local super market, Chennai. Casein powder was purchased from local company, Tamil Nadu. Maltodextrin (MD) and Guar gum were procured from M/s. Sigma Aldrich, Bangalore.

\section{Emulsion preparation}

The oil in water emulsion was prepared by using ingredients such as $10 \%$ olive oil, casein, maltodextrin and guar gum with different combinations.

Microencapsulation of oil was the formation of a fine and stable emulsion with core material inside the wall compound. Different ratios of wall material and oils were used for the microencapsulation study. Emulsions were passed in microfluidizer (Microfluidics, M$110 \mathrm{P})$ at $16000 \mathrm{psi}$ for fine emulsion formation.

\section{Emulsion characterization}

\section{Emulsion stability}

According to Tonon et al., (2012) emulsion stability was measured by the percentage of phase separation. After preparation of emulsion $25 \mathrm{~mL}$ of each sample were transferred to graduated cylinders, sealed, stored at room temperature for one day and the volume of the upper phase was measured after $24 \mathrm{~h}$. The percentage of separation is expressed as

$\%$ Separation $=\frac{H_{1}}{H_{0}} X 100$

Where $\mathrm{H}_{\mathrm{o}}$ represents the initial height of emulsion and $\mathrm{H}_{1}$ is the height of upper phase. 


\section{Emulsion viscosity}

Oil in water emulsion viscosity was measured using Brookfield viscometer (QCI-44). Viscosity is measure of fluid's resistance to flow. It is to drive a spindle (which is immersed in the test fluid) through a calibrated spring. The viscous drag of the fluid against the spindle is measured by the spring deflection. Spring deflection is measured with a rotary transducer. The viscosity is expressed in centipoise (cPs).

\section{Microencapsulation process by Spray drying}

The prepared emulsions was spray dried with a table top laboratory scale spray drier (SM Scientech, Kolkata) equipped with $0.75 \mathrm{~mm}$ atomizer nozzle. The compressed pressure of air for the flow of the spray was adjusted to 2.5 bars. The inlet air temperature $140^{\circ} \mathrm{C}$, $160^{\circ} \mathrm{C}, \quad 180^{\circ} \mathrm{C} \pm 5^{\circ} \mathrm{C}$ and outlet air temperature $50^{\circ} \mathrm{C}, 60^{\circ} \mathrm{C}, 70 \pm 5^{\circ} \mathrm{C}$ respectively were maintained with feed rate of 360-440 $\mathrm{mL} / \mathrm{h}$. All emulsions were prepared at the time of spray drying and prepared emulsion kept under magnetic stirrer. The microcapsules of oil powder were collected from the collecting chamber and transferred to tightly sealed polypropylene container and stored in darkness until further analysis. Various combinations of wall materials used for spray drying are shown in Table 1.

\section{Characterization of microencapsulated powder}

\section{Microencapsulation efficiency}

The microencapsulated olive oil powders were studied for its microencapsulation efficiency to assure the particles are well encapsulated. The encapsulation efficiency was analysed using the method described by Tan et al., (2005) by measuring total and surface oil content.

\section{Moisture content (\%) and water activity} $\left(\mathbf{a}_{\mathrm{w}}\right)$

The moisture content of microencapsulated olive oil powder was determined gravimetrically by drying in a vacuum oven at $70^{\circ} \mathrm{C}$ until constant weight (AOAC. 2006). The water activity of microencapsulated olive oil powder was measured by Rotronic Hygro Lab 3 water activity analyser (Model: awHP23).

\section{Flowing characteristics of}

Microencapsulated Olive Oil Powder (MOOP)

\section{Bulk density and tapped density}

Bulk density was determined according to Goula and Adamopoulos (2004). Two gram of powder (MOOP) was transferred to a $50 \mathrm{~mL}$ graduated cylinder. Packed bulk density was calculated from the weight of powder contained in the cylinder after being tapped by hand on a bench 50 times from a height of 10 $\mathrm{cm}$. The tap density was measured by pouring $10 \mathrm{~g}$ of microencapsulated olive oil powder into a $100 \mathrm{ml}$ graduated measuring cylinder. The cylinder was tapped 300 times on a table. Tap density measurement was repeated 3 times for each sample (Choi et al., 2010).

\section{Carr's index and Hausner ratio}

Flowability and cohesiveness of the powder were evaluated in terms of Carr's index (CI) (Carr, 1965) and Hausner ratio (HR) (Hausner, 1967), respectively. Both CI and HR were calculated from the bulk ( $\rho$-Bulk) and tapped ( $\rho$-Tapped) densities of the powder as shown below

Carr s Index $(C)=\frac{\text { Tapped density }(\rho T)-\text { Bulk density }(\rho B)}{\text { Tapped density }(\rho T)} \times 100$ 
Hausner Ratio $(H R)=\frac{\text { Tapped density }(\rho T)}{\text { Bulk density }(\rho \mathrm{B})}$

\section{Statistical analysis}

Statistical analysis of the data was done by analysis of variance (ANOVA) using SPSS software. Significance was accepted at 5\% level probability and Duncan's Multiple Range Test was used to compare mean variance. Data were expressed as mean values \pm standard error derived from determination of six replicates.

\section{Results and Discussion}

\section{Characterization of olive oil emulsion}

The viscosity and emulsion stability index of different emulsions were analysed before spray drying.

\section{Emulsion stability index}

The stability was observed in terms of phase separation of emulsions kept for 24 hours with $10 \%$ oil loads and different types of wall materials is shown in Table 2. From the stability of emulsion with different wall material combinations, it was found that emulsions prepared with combinations of maltodextrin/guar gum and Casein /maltodextrin/guar gum showed 100\% stability for 24 hours without phase separation while some emulsions were unstable casein/maltodextrin at 1:1ratio and casein/maltodextrin at $1: 2$ ratio shows small region of phase separation at 0.84 and 0.76 respectively.

The stability of emulsions produced with protein based wall material can be attributed to the unfolding of protein molecules at the surface of droplet, which enhances the protein-protein interaction, leading to flocculation during emulsification (Dickinson and Matsumura, 1991). The oil separation was higher in the emulsion prepared with a combination of Casein/maltodextrin at 1:1 ratio and the lowest oil separation was observed for the 1:2 proportions.

\section{Emulsion viscosity}

The viscosity of different combinations of wall material is shown in Table 2. The viscosity of emulsion increased with increasing wall material proportions and emulsion viscosity decreased with increasing proportion of maltodextrin as wall material systems. This result may be due to the size of proteins and modified starch molecules, since maltodextrin molecules are relatively smaller. Emulsions produced with casein were slightly more viscous than those prepared with maltodextrin.

The emulsion prepared with Casein/MD/GG combination was found to give maximum viscosity among all the carrier materials and emulsion prepared with maltodextrin alone as a wall material showed least viscosity. Bule $e t$ al., (2010) found that mixtures of gum arabic and maltodextrin combination had higher emulsion viscosity when compared to emulsions prepared with maltodextrin and other polymers.

Characterization of spray dried microencapsulated olive oil powder (MOOP)

\section{Microencapsulation efficiency}

Microencapsulation efficiency of different wall materials combination and processing parameters MOOP samples are shown in Figure 1.

The microencapsulation efficiency of different MOOP samples showed higher encapsulation efficiency $87.38,87.86,87.76$ and 88.76 for casein/MD at 1:1 ratio, casein/MD at 1:2 ratio, $\mathrm{MD} / \mathrm{GG}$ and casein/MD/GG respectively on 
inlet air temperature at $160^{\circ} \mathrm{C}$ when compared to $140^{\circ} \mathrm{C}$ and $180^{\circ} \mathrm{C}$. According to Barbosa et al., (2005) more stable emulsions had higher encapsulation efficiency whereas less stable emulsion gives lower amount of non encapsulated particles on the surface.

\section{Moisture content and water activity}

The moisture content (\%) and water activity $\left(a_{w}\right)$ of microencapsulated olive oil powder with different wall materials and processing parameters are shown in Table 3.

Moisture content of MOOP varied between $3.14 \%$ and $4.25 \%$ and showed a significant difference when different types of treatments with different air inlet temperatures. Increasing the inlet air temperature resulted in decrease in moisture content of the product as shown in Figure 2. Particles produced with casein/MD/ Guar gum treatment at $140^{\circ} \mathrm{C}$ air inlet temperature showed the highest moisture content, probably due to its high hygroscopicity in low air temperature, because it has many hydrophilic ramifications, which promote higher water adsorption from the ambient air. Microcapsules produced with casein/MD at 1:1 ratio had the lowest moisture content values.

Hogan et al., (2001) observed that the moisture content values of microencapsulated soybean oil by spray drying ranged from $1 \%$ to $3 \%$ and these values were not affected by the type of wall material as well. Ersus and Yurdagel (2007) reported that increasing spray drying temperature reduced the moisture content of powder. Moisture content ranged from 1.09 to 3.76 per cent for powder where the flow rates were kept constant at $5 \mathrm{ml} / \mathrm{min}$ for inlet air temperature which ranged between $160^{\circ} \mathrm{C}$ and $200^{\circ} \mathrm{C}$.

Water activity of different MOOP preparations showed a significant difference with different air inlet temperatures as given in Table 3. Increasing the inlet air temperature resulted in decrease in water activity of the product and the same is depicted in Figure 3.

Table.1 Proportion of wall materials to olive oil for microencapsulation

\begin{tabular}{|l|c|c|c|c|}
\hline \multirow{2}{*}{\multicolumn{1}{c|}{ Constituents }} & \multicolumn{4}{c|}{ Treatments } \\
\cline { 2 - 5 } & T1 & T2 & T3 & T4 \\
\hline Olive oil (g) & 100 & 100 & 100 & 100 \\
\hline Casein powder (g) & 100 & 100 & - & 100 \\
\hline Maltodextrin (MD) (g) & 100 & 200 & 198 & 198 \\
\hline Guar gum (GG) (g) & - & - & 2 & 2 \\
\hline Wall : Core ratio & $2: 1$ & $3: 1$ & $2: 1$ & $3: 1$ \\
\hline
\end{tabular}

Table.2 Physical characterization of different olive oil emulsion

\begin{tabular}{|c|c|c|}
\hline Treatments & $\begin{array}{c}\text { Emulsion stability } \\
\text { index(ESI) }\end{array}$ & Emulsion viscosity \\
\hline Casein/MD at 1:1 & $0.84^{\mathrm{b}} \pm 0.01^{* *}$ & $107.07^{\mathrm{b}} \pm 0.01$ \\
\hline Casein/MD at 1:2 & $0.76^{\mathrm{a}} \pm 0.01$ & $112.42^{\mathrm{c}} \pm 0.01$ \\
\hline MD/GG & $1.00^{\mathrm{c}} \pm 0.00$ & $87.13^{\mathrm{a}} \pm 0.01$ \\
\hline Casein/MD/GG & $1.00^{\mathrm{c}} \pm 0.00$ & $128.12^{\mathrm{d}} \pm 0.01$ \\
\hline
\end{tabular}

Average of six trials (Different superscripts in a row differ significantly)

$* *$ Values are expressed as Mean \pm S.E 
Table.3 Physical characteristics of Microencapsulated Olive Oil Powder (MOOP)

\begin{tabular}{|c|c|c|c|c|}
\hline Treatments & Inlet air temperature & Moisture Content (\%) & Water activity (aw) & $\begin{array}{l}\text { Microencapsulation } \\
\text { efficiency (ME) \% }\end{array}$ \\
\hline \multirow[t]{3}{*}{ Casein/MD at 1:1 } & $140^{\circ} \mathrm{C}$ & $4.09^{\mathrm{Ac}} \pm 0.01$ & $0.39^{\mathrm{Ac}} \pm 0.01$ & $84.75^{\mathrm{Aa}} \pm 0.13$ \\
\hline & $160^{\circ} \mathrm{C}$ & $3.72^{\mathrm{Ab}} \pm 0.01$ & $0.33^{\mathrm{Ab}} \pm 0.01$ & $87.38^{\mathrm{Ac}} \pm 0.19$ \\
\hline & $180^{\circ} \mathrm{C}$ & $3.14^{\mathrm{Aa}} \pm 0.01$ & $0.27^{\mathrm{Aa}} \pm 0.01$ & $86.62^{\mathrm{Ab}} \pm 0.10$ \\
\hline \multirow[t]{3}{*}{ Casein/MD at 1:2 } & $140^{\circ} \mathrm{C}$ & $4.13^{\mathrm{Bc}} \pm 0.01$ & $0.41^{\mathrm{ABc}} \pm 0.01$ & $84.91^{\mathrm{ABa}} \pm 0.20$ \\
\hline & $160^{\circ} \mathrm{C}$ & $3.79^{\mathrm{Bb}} \pm 0.01$ & $0.35^{\mathrm{Ab}} \pm 0.01$ & $87.86^{\mathrm{Bc}} \pm 0.13$ \\
\hline & $180^{\circ} \mathrm{C}$ & $3.27^{\mathrm{Ba}} \pm 0.01$ & $0.29^{\mathrm{ABa}} \pm 0.01$ & $86.33^{\mathrm{Ab}} \pm 0.20$ \\
\hline \multirow[t]{3}{*}{ MD/Guar gum } & $140^{\circ} \mathrm{C}$ & $4.19^{\mathrm{Cc}} \pm 0.01$ & $0.43^{\mathrm{Bc}} \pm 0.01$ & $85.27^{\mathrm{Ba}} \pm 0.11$ \\
\hline & $160^{\circ} \mathrm{C}$ & $3.87^{\mathrm{Cb}} \pm 0.01$ & $0.36^{\mathrm{ABb}} \pm 0.01$ & $87.76^{\mathrm{ABC}} \pm 0.12$ \\
\hline & $180^{\circ} \mathrm{C}$ & $3.31^{\mathrm{Ca}} \pm 0.02$ & $0.31^{\mathrm{Ba}} \pm 0.01$ & $86.75^{\mathrm{Ab}} \pm 0.09$ \\
\hline \multirow[t]{3}{*}{ Casein/MD/Guar gum } & $140^{\circ} \mathrm{C}$ & $4.25^{\mathrm{Dc}} \pm 0.01$ & $0.46^{\mathrm{Cc}} \pm 0.01$ & $85.98^{\mathrm{Ca}} \pm 0.17$ \\
\hline & $160^{\circ} \mathrm{C}$ & $3.95^{\mathrm{Db}} \pm 0.01$ & $0.39^{\mathrm{Bb}} \pm 0.01$ & $88.76^{\mathrm{Cc}} \pm 0.17$ \\
\hline & $180^{\circ} \mathrm{C}$ & $3.36^{\mathrm{Da}} \pm 0.01$ & $0.35^{\mathrm{Ca}} \pm 0.01$ & $87.55^{\mathrm{Bb}} \pm 0.20$ \\
\hline
\end{tabular}

Different letters indicate significant difference at $\mathrm{p} \leq 0.05$ (uppercase letters: between different wall materials; lowercase letters: between different air temperature) 
Table.4 Flow characteristics of Microencapsulated Olive Oil Powder (MOOP)

\begin{tabular}{|c|c|c|c|c|c|}
\hline Treatments & $\begin{array}{c}\text { Inlet Air } \\
\text { Temperature }\end{array}$ & $\begin{array}{l}\text { Bulk density } \\
\left(\mathrm{gmL}^{-1}\right)\end{array}$ & $\begin{array}{l}\text { Tapped density } \\
\left(\mathrm{gmL}^{-1}\right)\end{array}$ & Carr's Index & Hausner's Ratio \\
\hline \multirow[t]{3}{*}{ Casein/MD at $1: 1$} & $140^{\circ} \mathrm{C}$ & $0.31^{\mathrm{Ab}} \pm 0.01$ & $0.30^{\mathrm{Aa}} \pm 0.01$ & $13.89^{\mathrm{Cb}} \pm 0.01$ & $1.16^{\mathrm{Aa}} \pm 0.01$ \\
\hline & $160^{\circ} \mathrm{C}$ & $0.29^{\mathrm{Ab}} \pm 0.01$ & $0.33^{\mathrm{Aab}} \pm 0.01$ & $12.12^{\mathrm{Ba}} \pm 0.01$ & $1.14^{\mathrm{Aa}} \pm 0.01$ \\
\hline & $180^{\circ} \mathrm{C}$ & $0.24^{\mathrm{Aa}} \pm 0.01$ & $0.36^{\mathrm{Ab}} \pm 0.01$ & $20.01^{\mathrm{Cc}} \pm 0.01$ & $1.25^{\mathrm{Bb}} \pm 0.01$ \\
\hline \multirow[t]{3}{*}{ Casein/MD at 1:2 } & $140^{\circ} \mathrm{C}$ & $0.37^{\mathrm{Bc}} \pm 0.01$ & $0.36^{\mathrm{Ba}} \pm 0.01$ & $11.90^{\mathrm{Aa}} \pm 0.01$ & $1.14^{\mathrm{Ab}} \pm 0.01$ \\
\hline & $160^{\circ} \mathrm{C}$ & $0.35^{\mathrm{Bb}} \pm 0.01$ & $0.39^{\mathrm{Bb}} \pm 0.01$ & $10.26^{\mathrm{Aa}} \pm 0.01$ & $1.11^{\mathrm{Aa}} \pm 0.01$ \\
\hline & $180^{\circ} \mathrm{C}$ & $0.31^{\mathrm{Ba}} \pm 0.01$ & $0.42^{\mathrm{Bc}} \pm 0.01$ & $13.89^{\mathrm{Ac}} \pm 0.01$ & $1.16^{\mathrm{Ab}} \pm 0.01$ \\
\hline \multirow[t]{3}{*}{ MD/Guar gum } & $140^{\circ} \mathrm{C}$ & $0.34^{\mathrm{ABb}} \pm 0.02$ & $0.38^{\mathrm{Ba}} \pm 0.01$ & $17.07^{\mathrm{Da}} \pm 0.01$ & $1.21^{\mathrm{Ba}} \pm 0.01$ \\
\hline & $160^{\circ} \mathrm{C}$ & $0.32^{\mathrm{ABab}} \pm 0.01$ & $0.39^{\mathrm{Bab}} \pm 0.01$ & $17.95^{\mathrm{Db}} \pm 0.01$ & $1.23^{\mathrm{Ba}} \pm 0.02$ \\
\hline & $180^{\circ} \mathrm{C}$ & $0.29^{\mathrm{Ba}} \pm 0.01$ & $0.41^{\mathrm{Bb}} \pm 0.01$ & $23.68^{\mathrm{Dc}} \pm 0.02$ & $1.31^{\mathrm{Cb}} \pm 0.01$ \\
\hline \multirow{3}{*}{$\begin{array}{c}\text { Casein/MD/Guar } \\
\text { gum }\end{array}$} & $140^{\circ} \mathrm{C}$ & $0.33^{\mathrm{Ab}} \pm 0.01$ & $0.32^{\mathrm{Aa}} \pm 0.01$ & $13.16^{\mathrm{Ba}} \pm 0.01$ & $1.15^{\mathrm{Aa}} \pm 0.01$ \\
\hline & $160^{\circ} \mathrm{C}$ & $0.29^{\mathrm{Aa}} \pm 0.01$ & $0.35^{\mathrm{Ab}} \pm 0.01$ & $17.14^{\mathrm{Cb}} \pm 0.01$ & $1.21^{\mathrm{Bb}} \pm 0.01$ \\
\hline & $180^{\circ} \mathrm{C}$ & $0.26^{\mathrm{Aa}} \pm 0.01$ & $0.38^{A c} \pm 0.01$ & $18.75^{\mathrm{Bc}} \pm 0.01$ & $1.23^{\mathrm{Bb}} \pm 0.01$ \\
\hline
\end{tabular}

Different letters indicate significant difference at $\mathrm{p} \leq 0.05$ (uppercase letters: between different wall materials; lowercase letters: between different air temperature)

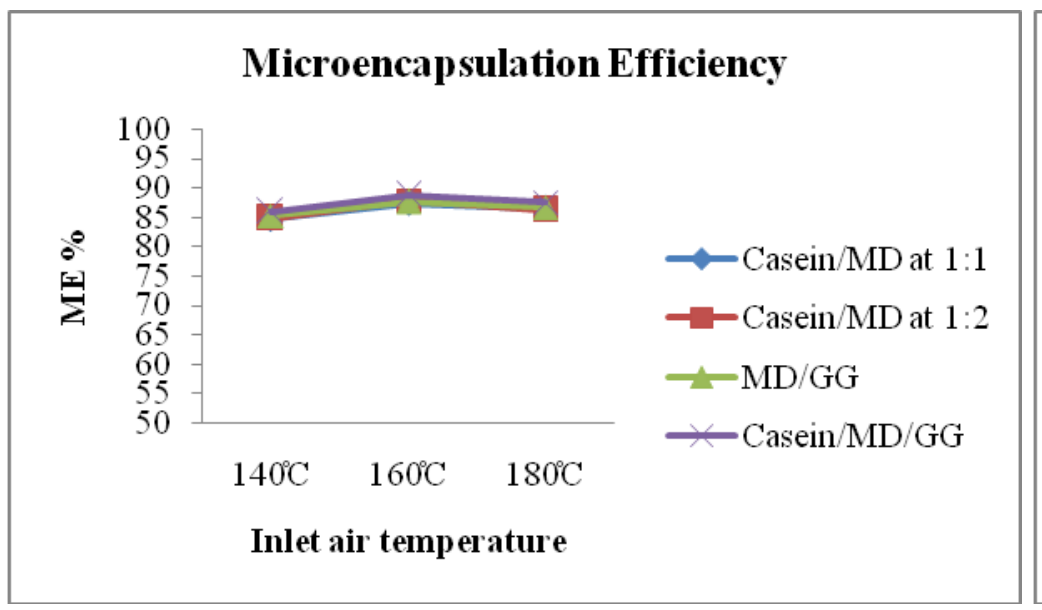

Fig.1 Microencapsualtion efficiency of MOOP

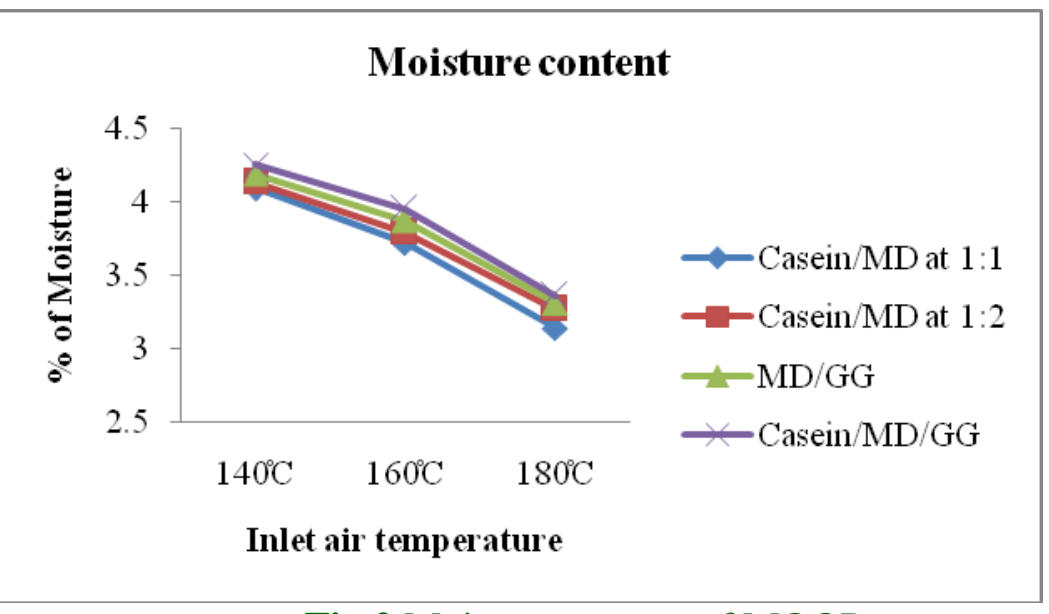

Fig.2 Moisture content of MOOP 


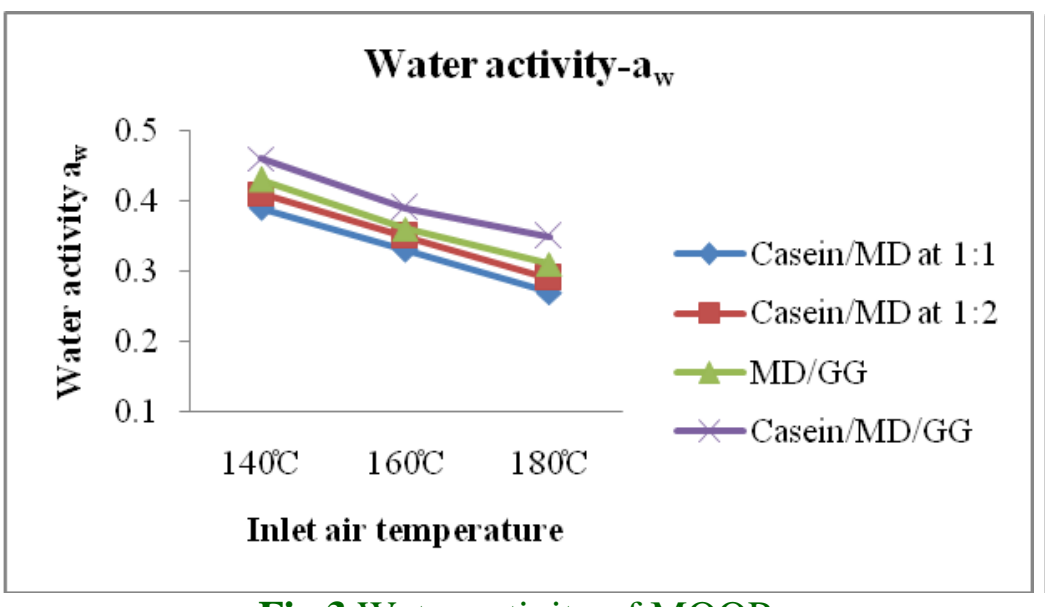

Fig.3 Water activity of MOOP

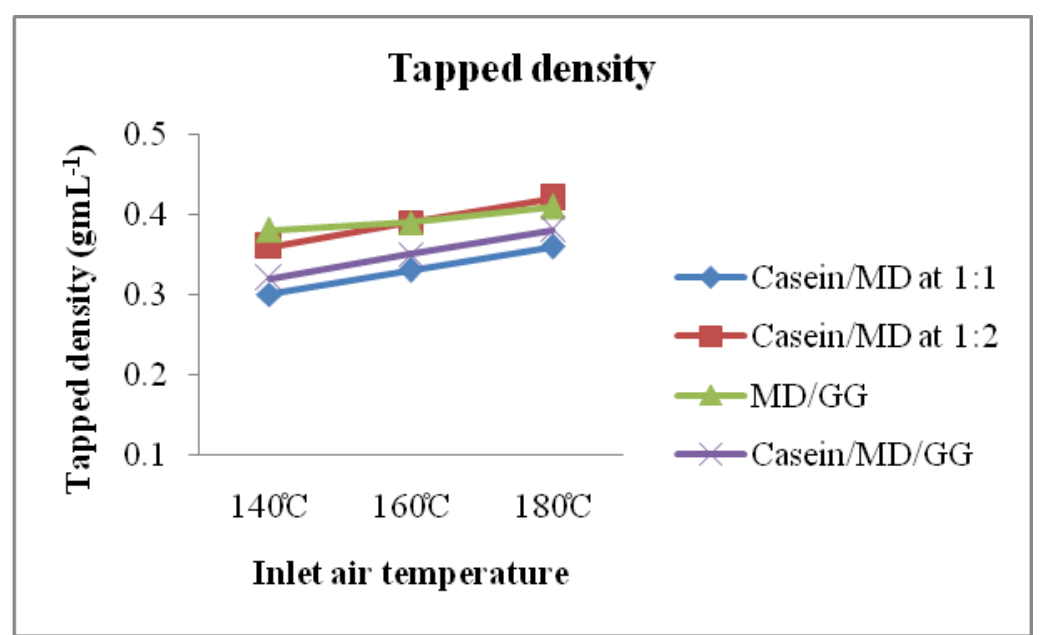

Fig.5 Tapped density of MOOP

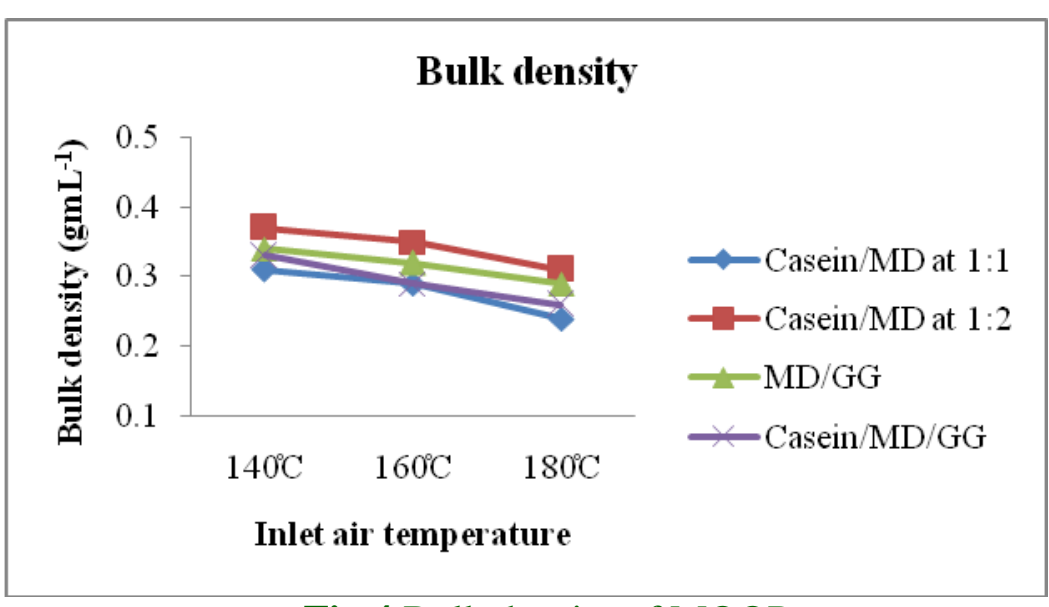

Fig.4 Bulk density of MOOP

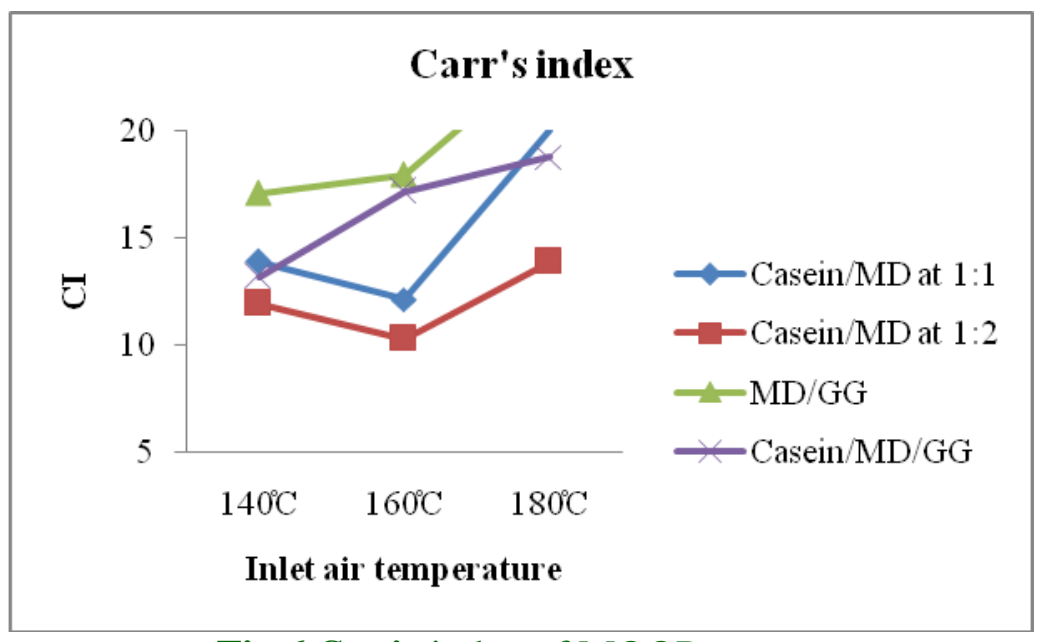

Fig.6 Carr's index of MOOP 


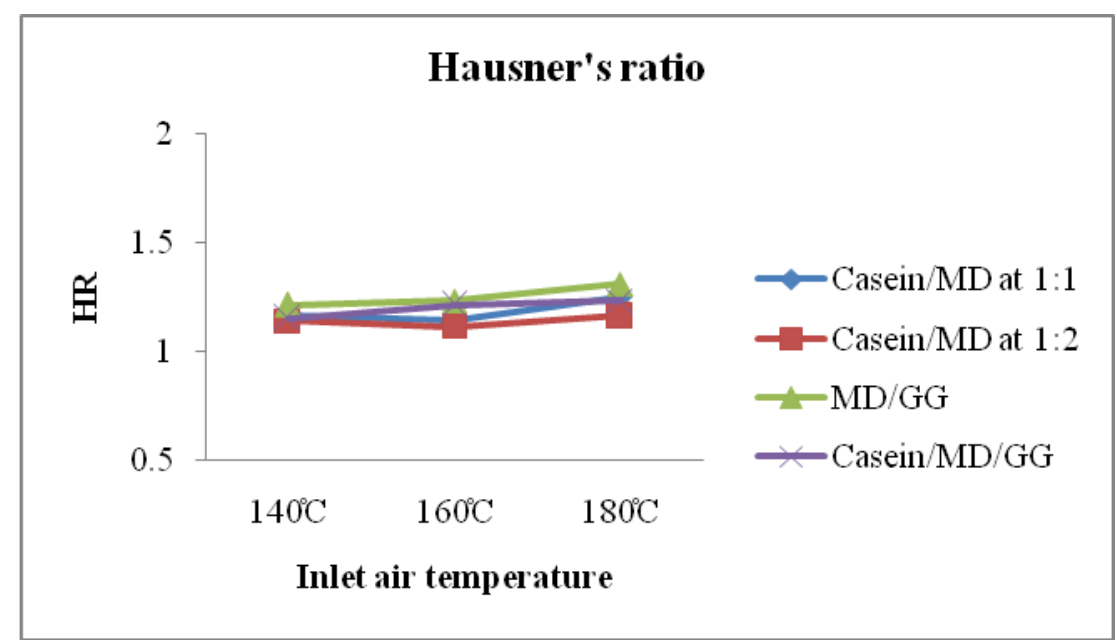

Fig.7 Hausner's ratio of MOOP

Flow characteristics of microencapsulated olive oil powder (MOOP)

\section{Bulk density and tapped density}

Bulk densities of four different MOOP ranged from 0.31 to 0.37 at an inlet air temperature of $140^{\circ} \mathrm{C}, 0.29$ to 0.35 at $160^{\circ} \mathrm{C}$ and 0.24 to 0.31 at $180^{\circ} \mathrm{C}$. The bulk density of Casein/MD/GG combination was found to be $0.33,0.29$ and 0.26 at an inlet air temperature of 140, 160 and $180^{\circ} \mathrm{C}$ respectively as presented in Table 4.

Bulk density of different microencapsulated olive oil powder has significantly decreased with increasing inlet air temperature as shown in Figure 4. According to Walton (2000), increasing inlet air temperature or decreasing rate of feed flow generally resulted in decrease in bulk density and there was a greater tendency for particles to be hollow. This could have resulted from a higher evaporation rate (Goula and Adamopoulos, 2008) or a lower residual moisture content (Chengini and Ghobadian, 2005), which may be the reason why bulk density decreased dramatically as the inlet air drying temperature increased.
Tapped density of four different MOOP ranged from 0.30 to 0.38 at an inlet air temperature of $140^{\circ} \mathrm{C}, 0.33$ to 0.39 at $160^{\circ} \mathrm{C}$ and 0.36 to 0.42 at $180^{\circ} \mathrm{C}$ as presented in Table 4 . The tapped density ratio of CP: MD combination at 1: 2 level was found to be $0.36,0.39$ and 0.42 at an inlet air temperature of $140{ }^{\circ} \mathrm{C}, 160^{\circ} \mathrm{C}$ and $180^{\circ} \mathrm{C}$ respectively.

Tapped density of different microencapsulated olive oil powder has significantly increased on increasing the inlet air temperature as shown in Figure 5.

The tapped density is an important factor for transport, packaging and marketing of powders and this variable is useful for determining the weight and amount of material that will fit inside a container (Finney et al., 2002).

Similar findings of Quispe-Condori et al., (2011) reported density of powder ranged from $0.35 \mathrm{~g} \mathrm{~mL}^{-1}$ to $0.49 \mathrm{~g} \mathrm{~mL}^{-1}$. The highest density was observed for the treatment prepared with gum arabic and inulin, which significantly differed $(\mathrm{p}<0.05)$ from all the other samples, except for the treatment prepared with gum arabic and maltodextrin. The high density dry product can be stored in 
a smaller container, compared with a low density product.

\section{Carr's index and Hausner ratio}

Effect of Carr's index (\%) and Hausner's ratio on flow properties is based on bulk and tapped density which is shown in Table 4.

Carr's index of microencapsulated olive oil powder showed marked variation based on different inlet air temperatures. Effect of bulk and tapped density of $\mathrm{CP} / \mathrm{MD}$ with $1: 1$ ratio showed $13.89,12.12$ and 20.00 at $140{ }^{\circ} \mathrm{C}, 160$ ${ }^{\circ} \mathrm{C}$ and $180^{\circ} \mathrm{C}$ inlet air temperature respectively and 1:2 ratio showed 11.90 , 10.26 and 13.89 at $140^{\circ} \mathrm{C}, 160^{\circ} \mathrm{C}$ and $180^{\circ} \mathrm{C}$ inlet air temperature respectively on Figure 6. The findings are in agreement with the results of Najmuddin et al., (2010) who reported the values of Carr's index and Hausner's ratio as "excellent type" flow properties.

Drusch et al., (2006) reported that the Carr's index of fish oil powder was in the range of 18.00 to 33.00 . The data obtained was important in predicting the flow property of coating materials. Malviya et al., (2009) reported that the flow characteristics of chitosan and gum arabic coacervates were good. Flow property is taken as major consideration because it helps to decide the ease of compaction of powder and Carr's index helps to evaluate compressibility characteristics of the composite complex.

Hausner's ratio of microencapsulated olive oil powder showed marked variation based on different inlet air temperatures. Effect of bulk and tapped density of $\mathrm{CP} / \mathrm{MD}$ with $1: 1$ ratio showed $1.16,1.14$ and 1.25 at $140{ }^{\circ} \mathrm{C}, 160^{\circ} \mathrm{C}$ and $180^{\circ} \mathrm{C}$ inlet air temperature respectively and $1: 2$ ratio showed $1.14,1.11$ and 1.16 at $140^{\circ} \mathrm{C}, 160^{\circ} \mathrm{C}$ and $180^{\circ} \mathrm{C}$ inlet air temperature respectively on Figure 7.
A Hausner's ratio of 1 to 1.25 indicates the powder is free flowing, 1.25 to 1.4 indicates fairly free flowing and that with greater than 1.4 are cohesive and do not flow well.

In conclusion, the present research work evaluated the performance of different combinations of wall material in the microencapsulation of olive oil by spray drying. The Casein/MD/GG combination showed the best encapsulation efficiency. According to the results, a mixture of casein, MD and guar gum with an inlet air temperature at $160^{\circ} \mathrm{C}$ could result in good moisture content and better encapsulation efficiency.

\section{References}

Association of Official Analytical Chemists. 2006. Official Methods of Analysis, 18th Ed; MD.

Bae, E. K and S. J. Lee. 2008. Microencapsulation of avocado oil by spray drying using whey protein and maltodextrin. J. Microencapsulation, 25, 549-560.

Barbosa, M. I. M. J., C. D. Borsarelli and A. Z. Mercadante. 2005. Light stability of spray dried bixin encapsulated with different edible polysaccharide preparations. Food Research International, 38 (8-9): 989-994.

Bule, M. V., Singhal, R. S., and Kennedy, J. F. 2010. Microencapsulation of ubiquinone-10 in carbohydrate matrices for improved stability. Carbohydrate Polymers, 82(4), 1290-1296.

Calvo, P., A. L. Castano, T. Hernandez and D. Gonzalez-Gomez. 2011. Effects of microcapsule constitution into the quality of microencapsulated walnut oil. European Journal of Lipid Science and Technology, 113: 1273-1280.

Calvo, P., T. Hernandez, M. Lozano and D. Gonzalez-Gomez.

2010. 
Microencapsulation of extra virgin olive oil by spray drying: Influence of wall material and olive quality. European Journal of Lipid Science and Technology, 112(8): 852-858.

Carr, R. L., 1965. Evaluating flow properties of solids. Chemical Engineering, 72: 163-168.

Chaiyasit, W., R. J. Elias, D. J. McClements and E. A. Decker. 2007. Role of physical structures in bulk oils on lipid oxidation. Critical reviews in food science and nutrition, 47(3): 299-317.

Chegini, G. R., and Ghobadian, B. (2005). Effect of spray-drying conditions on physical properties of orange juice powder. Drying Technology, 23(3), 657-668.

Choi, K. O., J. Ryu, H. S. Kwak and S. Ko. 2010. Spray dried conjugated linoleic acid encapsulated with Maillard reaction products of whey proteins and maltodextrin. Food Science and Biotechnology, 19(4): 957-965.

Coupland, J. N., and D. J. McClements. (1996). Lipid oxidation in food emulsions. Trends in Food Science and Technology, 7(3): 83-91.

Desorbry, S. A., F. M. Netto and T. B. Labuza.1997. Comparison of spray draying, drum drying and freeze drying for (1-3, 1-4)- b-carotene encapsulation and preservation. J. Food Sci., 62: 1158-1162.

Dickinson, E., and Y. Matsumura.1991. Time-dependent polymerization of $b$ lactoglobulin through disulphide bonds at the oil-water interface in emulsions. International Journal of Biological Macromolecules, 13(1): 26-30.

Drusch, S., Y. Serfert, A. Van Den Heuvel and K. Schwarz. (2006). Physicochemical characterization of fish oil encapsulated in an amorphous matrix containing trehalose. Food Res. Int., 39(1): 807-815.
Ersus, S and Yurdagel, U. (2007) Microencapsulation of anthocyanin pigments of black carrot (Daucus carota L.) by spray drier. Journal of Food Engineering, 80(3), 805-812.

Finney, J., R. Buffo and G. A. Reineccius. (2002). Effects of type of atomization and processing temperatures on the physical properties and stability of spray-dried flavors. Journal of Food Science, 67, 1108-1114.

German, B., E. J. Schiffrin, R. Reniero, B. Mollet, A. Pfeifer and J. R. Neeser. 1999. The development of functional foods: lessons from the gut. Trends in Biotechnology, 17(12): 492-499.

Goula, A. M., and K. G. Adamopoulos. 2004. Spray drying of tomato pulp: Effect of feed concentration. Drying Technology, 22(10): 2309-2330.

Hausner, H. H. (1967). Friction conditions in a mass of metal powder. International Journal of Powder Metallurgy, 3: 7-13.

Hogan, S. A., McNamee, B. F., O’Riordan, E. D., and O'Sullivan, M. (2001). Emulsification and microencapsulation properties of sodium caseinate/carbohydrate blends. International Dairy Journal, 11(3), 137144.

Hu, M., D. J. McClements and E. A. Decker. (2003). Impact of whey protein emulsifiers on the oxidative stability of salmon oil-in-water emulsions. Journal of Agricultural and Food Chemistry, 51(5): 1435-1439.

Malviya, R., P. Shukla and P. Srivastava. (2009). Preparation, characterization and evaluation of chitosan and gum arabic coacervates as excipient in fat dissolving/ disintegrating dosage form. J. Pharm. Sci., 34(5):13-23.

Najmuddin, M., S. Shelar, A. Ali, V. Patel and T. Khan. (2010), Formulation and in vitro evaluation of floating microspheres of ketoprofen prepared by 
emulsion solvent diffusion method. Inter. J. of Applied Pharma., 2(1):1317.

Quispe-Condori, S., M. D. A. Saldana and F. Temelli. (2011). Microencapsulation of flax oil with zein using spray and freeze drying. LWT - Food Science and Technology,44, 1880-1887.

Sun-Waterhouse, D., J. Zhou, G.M. Miskelly, R. Wibisono, S. S. Wadhwaa. 2011. Stability of encapsulated olive oil in the presence of caffeic acid. Food Chem. 126: 1049-1056.

Tan, L. H., Chan, L. W., and Heng, P. W. S. (2005). Effect of oil loading on microspheres produced by spray drying.
Journal of Microencapsulation, 22(3), 253-259.

Tonon, R. V., R. B. Pedro, C. R. Grosso and M. D. Hubinger. (2012). Microencapsulation of flaxseed oil by spray drying: Effect of oil load and type of wall material. Drying Technology, 30(13): 1491-1501.

Young, S. L., X. Sarda and M. Rosenberg. (1993). Microencapsulating properties of whey proteins. 2. Combination of whey proteins with carbohydrates. Journal of Dairy Science, 76(10): 28782885.

\section{How to cite this article:}

Ashokkumar, C., B. Murugan, D. Baskaran, V. Veerapandian and Karthiayani, A. 2018. Effect of Wall Materials and Inlet Air Temperatures on Physical Properties of Microencapsulated of Olive Oil Powder. Int.J.Curr.Microbiol.App.Sci. 7(05): 2391-2402. doi: https://doi.org/10.20546/ijcmas.2018.705.275 